\title{
Magyarországi intenzív osztályok szervdonációval kapcsolatos személyi és tárgyi feltételei
}

\author{
Mihály Sándor dr. ${ }^{1}$ - Egyed-Varga Anita ${ }^{1}$. Holtzinger Emese ${ }^{1}$ \\ Kara Kristóf ${ }^{1}$ - Ezer Erzsébet dr. ${ }^{2}$. Szedlák Balázs dr. ${ }^{3}$ \\ Smudla Anikó dr. ${ }^{4}$ - Nacsa János dr. ${ }^{1}$ - Matusovits Andrea dr. ${ }^{1}$ \\ ${ }^{1}$ Országos Vérellátó Szolgálat, Budapest \\ ${ }^{2}$ Pécsi Tudományegyetem, Általános Orvostudományi Kar, Idegsebészeti Klinika, Pécs \\ ${ }^{3}$ Borsod-Abaúj-Zemplén Megyei Központi Kórház és Egyetemi Oktató Kórház, \\ Központi Aneszteziológiai és Intenzív Terápiás Osztály, Miskolc \\ ${ }^{4}$ Semmelweis Egyetem, Általános Orvostudományi Kar, Transzplantációs és Sebészeti Klinika, Budapest
}

\begin{abstract}
Bevezetés: A hazai transzplantációs várólistákon 2016 végén kétszer annyi beteg volt, mint amennyi átültetés történt az év során. A szervdonációs programok múködésének intézményi szintû előfeltétele a megfelelő dolgozói létszám és a tárgyi feltételek biztosítása az ellátási szükséglethez képest.

Célkitüzés: A jelen vizsgálat célja a hazai szakmai környezet feltérképezése volt.

Módszer: Az Országos Vérellátó Szolgálat Szervkoordinációs Irodája kérdőíves felmérést készített a magyarországi intenzív osztályok szervdonációval kapcsolatos személyi és tárgyi feltételeiről. A felmérés eszköze online kérdőív volt, 43 kérdéssel. Az ágyszámok és a dolgozói létszám mellett vizsgáltuk az agyhalál jogi és orvosszakmai megállapításához szükséges eszközöknek, valamint a donorlekérdezőn található vizsgálatoknak az elérhetőségét. Az adatgyújtés 2016. december 12-tôl 2017. június 30-ig tartott.

Eredmények: A kérdőívet 59 kórház intenzív osztálya töltötte ki; a vizsgálat 640 betegágyat, 816 orvost, valamint 1252 ápolót érintett. Nappali múszakban egy betegágyra átlagosan 0,25 orvos, 0,41 ápoló jut, éjszakai múszakban 0,11 és 0,33 . Az Országos Transzplantációs Nyilvántartásból való lekérdezésre az orvosok 51,7\%-a regisztrált, agyhalál-megállapító bizottság a kórházak 83\%-ában bármikor elérhető. A képalkotó vizsgálatok között (koponya, hasmellkas) CT-vizsgálat 71-73\%-ban, hasi UH 75\%-ban, transthoracalis echokardiográfia 37\%-ban, transoesophagealis echokardiográfia 4\%-ban, bronchoszkópia 49\%-ban, koronarográfia 19\%-ban nonstop elérhető, 75\%-ban azonnali leletezéssel. Transcranialis Doppler-vizsgálat 30\%-ban, négyér-angiográfia 45\%-ban és SPECT 14\%-ban áll rendelkezésre. A donorlekérdezőn szereplő laborvizsgálatok több mint 90\%-a a nap 24 órájában elérhető.

Következtetés: A 2008-ban történt felmérésünkhöz képest az orvosok és az ápolók száma nem változott (2008: 0,18 orvos; 0,37 ápoló/intenzív osztályos ágy), miközben egy potenciális donor ellátása egyre több erőforrást és időt igényel. A személyi és tárgyi feltételek rendelkezésre állása a szervdonációs programok előfeltétele az életmentés szolgálatában.
\end{abstract}

Orv Hetil. 2018; 159(33): 1360-1367.

Kulcsszavak: szervdonáció, szervátültetés, intenzív ellátás

\section{Personnel and material conditions of the Hungarian intensive care units dealing with organ donation}

Introduction: At the end of 2016, the number of patients on the domestic transplant waiting list was twice as much as the number of the organ transplantations accomplished that year. The institutional prerequisites for functional organ donation programs are the sufficient number of personnel and the adequate material conditions to be provided in relation to the needs.

Aim: The goal of the current study was to evaluate the professional environment in Hungary.

Method: The Organ Coordination Office at the Hungarian National Blood Transfusion Service compiled a questionnaire survey on the personnel and material conditions of the intensive care units (ICUs) in Hungary in regards to organ donations. The survey applied an online questionnaire including 43 questions. In addition to the number of 
beds and employees, we investigated the tools needed for the legal and the medical diagnosis of brain death as well as the accessibility of examinations on the donor information form. The data collection spanned from 12 December 2016 to 30 June 2017.

Results: 59 intensive care units completed the questionnaire; the investigation involved 640 hospital beds, 816 physicians and 1252 nurses. In the daytime shift, 0.25 doctors and 0.41 nurses work on a patient bed at an average, while in the night shift, the figures are 0.11 and 0.33 , respectively. $51.7 \%$ of the doctors are registered to access the National Non-Donor Registry, and brain death diagnosis committee is available in $83 \%$ of the hospitals. Among the medical imaging methods (cranial, abdominal-thoracic), CT scan in 71-73\%, abdominal ultrasound in 75\%, transthoracic echocardiograpy (TTE) in 37\%, transoesophageal echocardiography (TEE) in 4\%, bronchoscopy in 49\%, coronarography in $19 \%$ are non-stop available, with instant interpretation in $75 \%$ of the cases. Transcranial Doppler (TCD) in 30\%, four-vessel angiography in $45 \%$ and SPECT in $14 \%$ of the cases are available. More than $90 \%$ of the laboratory examinations on the donor information form are available 24 hours a day.

Conclusion: The number of doctors and nurses did not change compared to our 2008 survey ( 0.18 doctors, 0.37 nurses/ICU beds in 2008), but the care of potential donors needs more resources and time. The standby availability of personnel and material conditions is a prerequisite for organ donation programs in order to save lives.

Keywords: organ donation, organ transplantation, critical care

Mihály S, Egyed-Varga A, Holtzinger E, Kara K, Ezer E, Szedlák B, Smudla A, Nacsa J, Matusovits A. [Personnel and material conditions of the Hungarian intensive care units dealing with organ donation]. Orv Hetil. 2018; 159(33): 1360-1367.

(Beérkezett: 2018. március 27.; elfogadva: 2018. április 26.)

\section{Rövidítések}

CT = komputertomográfia; ESzCsM = Egészségügyi, Szociális és Családügyi Minisztérium; ITO = intenzív osztály; NSzR = Nemzeti Szervdonációs Regiszter; OEP = Országos Egészségbiztosítási Pénztár; OTNY = Országos Transzplantációs Nyilvántartás; OVSZ = Országos Vérellátó Szolgálat; SBO = Sürgősségi Betegellátó Osztály; TCD = transcranialis Doppler; $\mathrm{TEE}=$ transoesophagealis echokardiográfia $;$ TTE $=$ transthora calis echokardiográfia

Az elmúlt 50 évben a szervátültetés gyakorlata világszerte elterjedt, ami a várólistára kerülő betegek túlélési esélyeit érdemben növelte. Az utóbbi két évtizedben folyamatosan nő a szervátültetések száma. A veseátültetés a végstádiumú veseelégtelenségben szenvedő betegek számára a leginkább költséghatékony vesepótló eljárás az összes elérhető alternatíva között, illetve a transzplantáció a máj, a szív és a tüdő végstádiumú betegségeiben az egyetlen elérhető terápia [1].

Az Egészségügyi Világszervezet adatai szerint évente körülbelül 200 ezer ember kerül fel transzplantációs várólistára a világon, míg az éves transzplantációs esetszám közel 120 ezer volt 2015-ben [2]. Az Európai Unióban 2015-ben 143 ezer ember várt megfelelő donorszervre, miközben naponta 18 beteg halt meg a várakozás közben [3]. Magyarországon is hasonló a várólisták igénye, hiszen 2016 utolsó napján is kétszer annyi beteg várt hazai transzplantációs várólistán donorszervre, mint amennyi átültetés történt az egész év során [4].

Ha a szervátültetésre várók számának növekedése meghaladja a növekvő transzplantációs esetszámot, akkor csökken a szervhez jutás egyéni esélye, illetve a váró- listán lévơk állapotromlásához vezet. Így rosszabb aktuális testi kondíciók mellett kell elvégezni a transzplantációt, vagy más esetekben a radikális állapotromlás halállal végződhet.

Emiatt fontos a hazai szervdonációs potenciál - a szervdonációra alkalmas összes agyhalott - felkutatása, valamint az elmaradt donorjelentések okainak elemzése. A szervdonációs programok múködésének intézményi szintü előfeltétele a megfelelő dolgozói létszám és a tárgyi feltételek biztosítása az ellátási szükséglethez képest. A jelen vizsgálat célja a hazai szakmai környezet feltérképezése volt.

\section{Módszer}

Az Országos Vérellátó Szolgálat Szervkoordinációs Irodája kérdőíves felmérést végzett a magyarországi intenzív osztályok szervdonációval kapcsolatos személyi és tárgyi feltételeiről. A felmérés eszköze egy 43 kérdést tartalmazó online kérdőív volt. A dolgozók létszámát összesen és egy mûszakra számítva is összehasonlítottuk az ágyszámmal. A tárgyi feltételek felmérése során az agyhalál jogi és orvosszakmai megállapításához szükséges eszközök, valamint a magyar donorlekérdezőn található vizsgálatok elérhetőségét mértük fel. A kérdőív kitöltését a donorjelentő kórházak főorvosaitól kértük, akik számára direkt hozzáférést biztosítottunk a kitöltéshez: https://googl/forms/sO0teWTRnobErO9W2. Az adatgyüjtés 2016. december 12-től 2017. június 30-ig tartott. Két kórház kivételével minden olyan kórházat ( $n=41)$ be tudtunk vonni a felmérésbe, ahonnan 2016ban donorjelentés érkezett. További 18, 2016-ban donort nem jelentő kórház is kitöltötte a kérdőívet. 


\section{Eredmények}

\section{Személyi feltételek}

A személyi feltételek felmérése 59 intenzív osztályon öszszesen 640 betegágyat érintett. A kérdőívben megkérdeztük az adott osztályon dolgozók létszámát, így a vizsgálat összesen 607 szakorvosra, 209 rezidensre és 1252 ápolóra terjedt ki. Egy ágyra átlagosan 0,95 szakorvos, 0,33 rezidens, 1,28 orvos (szakorvos és rezidens együtt) és 1,96 ápoló jut. Van olyan kórház, ahol összesen 2 szakorvos dolgozik fóállásban, míg a maximum 33 volt. A rezidensek száma átlagosan kórházanként 3,53. Átlagosan 21,21, minimum 8 ápoló dolgozik egy intenzív osztályon (1. táblázat).

Felmértük az osztályon dolgozó és egy műszakban dolgozó orvosok, illetve ápolók számát, és a létszámot egy betegágyhoz viszonyítottuk. A kérdőív alapján alapvetően megkülönböztethető az orvosoknál a hétköznapi (nappal és éjjel), illetve a hétvégi, ünnepnapi műszak. Hétköznap munkaidőben, illetve a munkaidő után másnap reggelig látják el feladataikat. Hétvégén, illetve ünnepnapokon 24 órás müszakokban dolgoznak. Néhány kórházban $(\mathrm{n}=3)$ van lehetőség telefonos készenlétes szakorvos behívására éjjel és hétvégén. Az ápolók minden kórházban 12 órás múszakban dolgoznak.

A beérkező válaszok alapján az orvosok 91,53\%-ban ügyeleti rendben dolgoznak, hétköznap munkaidőben, valamint munkaidőn túl, hétvégén és ünnepnapokon 24 órában.

$\mathrm{Az}$ eredmények értelmezésekor figyelembe kell venni az osztályonként különböző munkarendek alkalmazását. A válaszban külön említett fönővért beszámítottuk az ápolói múszaklétszámba. Egy nappali múszakban átlagosan 2,75 orvos és 4,65 ápoló dolgozik, míg az egy betegágyra jutó orvosok, illetve ápolók száma 0,25 és 0,41 a nappali múszakban. Éjszakai müszakban átlagosan 1,3 orvos és 3,75 ápoló dolgozik, míg az egy betegágyra jutó orvosok és ápolók száma éjjel 0,11 és 0,33 (2. táblázat).

Statisztikai módszerekkel vizsgáltuk az ágykihasználtság, a szervdonációk száma, valamint az orvosok és az ápolók száma közötti összefüggést. Az egyik vizsgálatban a donációk számát mint skálaváltozót használtuk, utána pedig kategorizált (volt donáció - nem volt donáció; illetve 0, 1-5, 6 feletti kategória) összehasonlítást alkalmaztunk. Egyik esetben sem találtunk szignifikáns összefüggést a szervdonációs aktivitás és a dolgozói (orvos és ápoló is) létszám között.

A 60/2003. (X. 20.) számú, az egészségügyi szolgáltatások nyújtásához szükséges szakmai minimumfeltételekről szóló ESzCsM rendelet leírja a kórház intézeti szintjétől függő minimum szükséges személyzeti létszámot betegágyakra viszonyítva műszakonként. Ennek értelmében a városi kórházakban optimális orvos és ápoló/betegágy arány mindkét esetben 1 : 3 müszakonként. Ez az arány a megyei kórházak esetében orvosokra viszo-
1. táblázat |Személyi feltételek magyarországi intenzív osztályokon

\begin{tabular}{lcccc}
\hline & Betegágy & Szakorvos & Rezidens & Ápoló \\
\hline Elemszám & 59 & 59 & 59 & 59 \\
\hline Minimum & 5 & 2 & 0 & 8 \\
\hline Maximum & 31 & 33 & 20 & 59 \\
\hline Átlag & 10,85 & 10,29 & 3,53 & 21,21 \\
\hline Szórás & 5,42 & 7,43 & 4,49 & 12,86 \\
\hline Medián & 10 & 8 & 2 & 18 \\
\hline Összesen & 640 & 607,20 & 209 & 1251,50 \\
\hline
\end{tabular}

2. táblázat $\mid$ Személyi feltételek magyarországi intenzív osztályokon müszakonként

\begin{tabular}{lcccc}
\hline & $\begin{array}{c}\text { Orvosok } \\
\text { nappal }\end{array}$ & $\begin{array}{c}\text { Ápolók } \\
\text { nappal }\end{array}$ & $\begin{array}{c}\text { Orvosok } \\
\text { éjjel }\end{array}$ & $\begin{array}{c}\text { Ápolók } \\
\text { éjjel }\end{array}$ \\
\hline Elemszám & 57 & 57 & 56 & 57 \\
\hline Minimum & 1 & 2 & 1 & 2 \\
\hline Maximum & 8 & 15 & 4 & 10 \\
\hline Átlag & 2,75 & 4,65 & 1,30 & 3,75 \\
\hline Szórás & 1,80 & 2,55 & 0,66 & 2,01 \\
\hline Medián & 2 & 4 & 1 & 3 \\
\hline Szum & 157 & 265 & 73 & 214 \\
\hline $\begin{array}{l}\text { Egy betegágyra } \\
\text { számított } \\
\text { dolgozói létszám }\end{array}$ & 0,25 & 0,41 & 0,11 & 0,33 \\
\hline & & & & \\
\hline
\end{tabular}

nyítva múszakonként 1 : 2, ápolók esetében 1 : 1,6 müszakonként. Az egyetemi/országos intézményekben az optimális orvos/betegágy arány múszakonként $1: 2$, ápolók esetében $1: 1$.

A kérdőívben 57 kórház rögzítette az egyes műszakok létszámait az intenzív osztályon (3. táblázat).

Jelentős különbségek tapasztalhatók mind az orvosi, mind az ápolói létszám terén a városi, a megyei és az egyetemi intézmények között, elsősorban az utóbbiak javára. Kifejezetten néhány városi kórházban tapasztaltunk olyan feltételeket, amelyek mellett a mindennapi betegellátás is komoly kihívást jelenthet. Bár a statisztika szerint ezekben az intézményekben az ápolói létszám átlaga meghaladja a minimumfeltételekben eloórtakat, ez megtévesztő, hiszen jelentősen torzító tényező ezen osztályok alacsony ágyszáma (átlag: 8,3, medián: 7), melyhez viszonyítva a múködésképességhez feltétlenül szükséges létszám rögtön egy jobb arányt eredményez (3. táblázat).

A potenciális donorok felismerésére, jelentésére és a folyamat végigvitelére több okból is negatívan hatnak az elégtelen személyi feltételek. Ha súlyos agykárosodást szenvedett beteg érkezik egy sürgősségi osztályra, kapacitáshiány miatt gyakran nem vagy későn történik meg az áthelyezés az intenzív osztályra, különösen, ha az átvételt bármelyik fél donorgondozási céllal kezdeményezi. Ezt 
Egy ágyra jutó orvosok és ápolók száma a Szervkoordináció Iroda felmérései alapján, összevetve a minimumfeltételekról szóló $60 / 2003$. (X. 20.) ESzCsM rendelet irányszámaival

\begin{tabular}{lcccc}
\hline $\begin{array}{l}\text { Egy ágyra számított } \\
\text { dolgozói létszám }\end{array}$ & $\begin{array}{c}\text { Orvosok } \\
\text { nappal }\end{array}$ & $\begin{array}{c}\text { Ápolók } \\
\text { nappal }\end{array}$ & $\begin{array}{c}\text { Orvosok } \\
\text { éjjel }\end{array}$ & $\begin{array}{c}\text { Ápolók } \\
\text { éjjel }\end{array}$ \\
\hline Országos adat & 0,25 & 0,41 & 0,11 & 0,33 \\
Városi & 0,25 & 0,42 & 0,16 & 0,36 \\
Megyei & 0,23 & 0,44 & 0,09 & 0,30 \\
Egyetemi és országos & 0,33 & 0,46 & 0,13 & 0,40 \\
intézet & & & &
\end{tabular}

intézet

\begin{tabular}{|c|c|c|}
\hline \multicolumn{3}{|c|}{$\begin{array}{c}\text { Minimumfeltételek (60/2003. (X. 20.) ESzCsM rendelet) } \\
\text { és az eredmények összehasonlítása }\end{array}$} \\
\hline & Orvos/betegágy & Ápoló/betegágy \\
\hline Városi & 0,33 & 0,33 \\
\hline Megyei & 0,50 & 0,63 \\
\hline $\begin{array}{l}\text { Egyetemi és országos } \\
\text { intézet }\end{array}$ & 0,50 & 1,00 \\
\hline 2002-ben országos átlag & 0,22 & 0,33 \\
\hline 2008-ban országos átlag & 0,18 & 0,37 \\
\hline 2017-ben országos átlag & 0,18 & 0,39 \\
\hline
\end{tabular}

4. táblázat | Donorjelentések száma és a jelentés elmaradásának okai 18 kórházi koordinátori intézményben 2016-ban

Donorjelentés Szervkoordinációs Iroda felé és a jelentések elmaradásának okai (2016. 01. 01. - 2016. 12.31.)

\begin{tabular}{lc}
\hline Donorjelentés Szervkoordinációs Iroda felé & $114(100 \%)$ \\
\hline A donorjelentés elmaradásának oka: kapacitáshiány & $1(2,7 \%)$ \\
\hline $\begin{array}{l}\text { A donorjelentés elmaradásának oka: nem merült fel } \\
\text { a szervdonáció lehetősége }\end{array}$ & $10(27,03 \%)$ \\
\hline $\begin{array}{l}\text { A donorjelentés elmaradásának oka: rendőrségi } \\
\text { engedély megtagadva }\end{array}$ & $1(2,7 \%)$ \\
\hline $\begin{array}{l}\text { A donorjelentés elmaradásának oka: család } \\
\text { visszautasítja a donáció lehetőségét }\end{array}$ & $2(5,41 \%)$ \\
\hline $\begin{array}{l}\text { A donorjelentés elmaradásának oka: abszolút vagy } \\
\text { relatív kontraindikáció }\end{array}$ & $23(62,16 \%)$ \\
\hline
\end{tabular}

támasztják alá a kórházi koordinátori minőségbiztosítási program során 2016-ban a Nemzeti Szervdonációs Regiszterben gyüjtött 3071 donor auditeredményei is (4. táblázat).

$\mathrm{Az}$ orvosok (szakorvos és rezidens együttesen) 51,70\%-a rendelkezik az Országos Transzplantációs Nyilvántartásnak (OTNY), vagyis a tiltakozóregiszternek a lekérdezéséhez szükséges jogosultsággal $(\mathrm{n}=422)$, ami kórházanként átlagosan 7,28 orvost jelent (kórházanként átlagosan 13,83 orvos között). A jogosultsággal rendelkezők száma kórházanként maximum 37 (ahol 43 orvos dolgozik) és minimum 0.

Az agyhalál-megállapító bizottság a válaszadó kórházak (n = 58) 82,76\%-ában bármikor összehívható. Főigazgatói kinevezéssel ( $\mathrm{n}=58$ ) az orvosok 94,84\%-a rendelkezik, eseti kinevezés 5,17\%-ban fordul elő.

\section{Tárgyi feltételek}

Vizsgáltuk az internetkapcsolat elérhetőségét az osztályokon $(n=59)$, amely a szervdonációs folyamat kórházi lebonyolításához szükséges. A válaszokból kiderül, hogy 71,19\%-ban van internet, de van, ahol korlátozottan érhető el $(27,12 \%)$, és van, ahol az egyéb kategória került kiválasztásra (1,69\%).

Az Országos Transzplantációs Nyilvántartással való kapcsolattartásra is tekintettel kitértünk a faxkészülék elérhetőségének vizsgálatára $(\mathrm{n}=59)$. A válaszadó intézmények 71,19\%-ában a nap 24 órájában elérhető, 15,25\%-ban az intézményen belül máshol, de csak munkaidőben, 5,08\%-ban pedig kizárólag munkaidőben van faxhasználatra lehetőség. A válaszadók 8,71\%-a a kórházon belüli egyéb lehetőséget jelölte meg, azonban van olyan kórház, ahol nincs elérhető készülék. Az utóbbi intézményből utoljára 2010-ben érkezett donorjelentés.

Kitértünk a tárgyi feltételek vizsgálatakor az ágymérleg elérhetőségére, mely a potenciális donor pontos testsúlyának megadásához és az életmentő szervek allokációjához fontos, hiszen a legtöbb esetben becsült testsúlyt adnak meg. A válaszadó kórházak $(\mathrm{n}=58) 79,31 \%$-a nem rendelkezik ágymérleggel.

\section{Képalkotó vizsgálatok}

Vizsgáltuk a kérdőívben a donorértékeléshez szükséges képalkotó vizsgálatok rendelkezésre állását, illetve a potenciális donor szállíthatóságát befolyásoló tényezőként megkérdeztük, hol érhetők el a vizsgálatok. Külön vizsgáltuk a mellkas-has CT, a koponya-CT és a kardio-CT elérhetőségét. A CT-vizsgálatok megléte nem kötelező a donorértékeléshez, azonban az anamnézis vagy más képalkotó eredmény alapján felmerülhet a szükségessége. A potenciális donor másik intézménybe történő szállítása nem biztonságos, a szállítás során bekövetkező keringésösszeomlás kockázata miatt (5. táblázat).

Van olyan kórház, ahol a mellkasröntgen helyben elérhető 0-24 órában, viszont hasi ultrahangra csak munkaidőben van lehetőség. Ez a két vizsgálat a szervalkalmasság megítéléséhez elengedhetetlenül szükséges, és az intézmények legnagyobb részében a nap 24 órájában elérhető.

A kiterjesztett donorkritériumok miatt ma már a legtöbb potenciális donornál felmerül a szív átültetésre való alkalmassága, melynek megítéléséhez az elsőként választandó vizsgálat a szívultrahang (TTE). Ez a vizsgálat a kórházak felében nem érhető el munkaidőn kívül, ami befolyásolhatja a szervkivételi mútét kezdetének időpontját is. A kérdőívben kitértünk a TEE (transoesophagealis echokardiográfia) elérhetőségére is (5 esetben nem érkezett válasz).

A tüdő alkalmasságának megítéléséhez szükséges lehet a bronchoszkópia, ami sokszor éjszaka merül fel. Önmagában a vizsgálat hiánya általában nem hiúsít meg tüdőeltávolítást, és a vizsgálatkérő számít is arra, hogy nem 
5. táblázat |A képalkotó vizsgálatok elérhetőségei magyarországi intenzív osztályokon

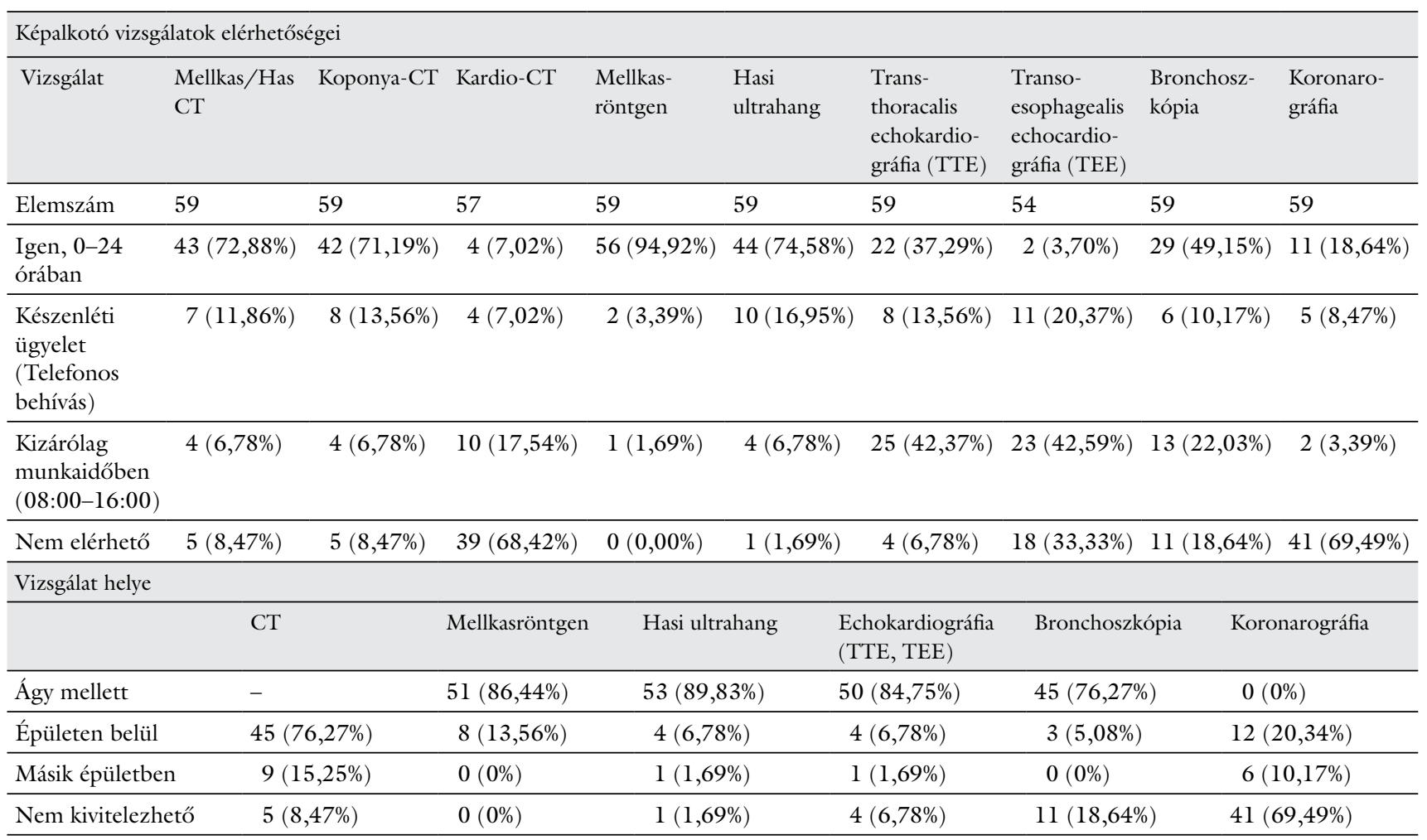

feltétlenül pulmonológus tudja elvégezni. Meglepő, hogy 11 kórházban nem érhető el a vizsgálat, holott az intenzív osztályok alapvető felszereltségéhez hozzátartozik az eszköz.

Idősebb, magas kockázatú csoportba eső donoroknál a szívultrahang-eredmény ismeretében koronarográfia is indokolt. Marginális donorok esetében ennek hiányában jelentősen csökken a valószínűsége, hogy elfogadják a szervet olyan centrumok, amelyeknek messziról érkezve, költséges légi szállítást is igénybe kell venniük egy bizonytalan alkalmasságú donorszerv miatt. Sajnos ez a vizsgálat csak 18 kórházban érhető el.

A kérdőívben megkérdeztük, hogy az elkészült képalkotó vizsgálatok leletezése mennyi időn belül valósítható meg. Az esetek 74,58\%-ában azonnali leletezésre van lehetőség a nap 24 órájában, 13,56\%-ban munkaidőn túl, készenléti radiológus leletez, 10,17\%-nál csak munkaidőben, és egy kórházban munkaidőn túl nincs leletezés (5. táblázat).

\section{Kiváltó vizsgálatok}

A kérdőívvel vizsgáltuk a hiányzó agymüködés irreverzibilitását bizonyító mûszeres vizsgálat elérhetőségét, amely a megfigyelési idő lerövidítését, kiváltását szolgálja. Transcranialis Doppler (TCD) a kórházak 16,95\%ánál csak munkaidőben van, 8,47\%-nál telefonos készenléti ügyeletes végzi el a vizsgálatot, és csupán 5,08\%-ban van lehetőség a vizsgálat elvégzésére napi 24 órában.
A TCD-vizsgálat a válaszadók 30,51\%-ánál ágy mellett, 3,39\%-ánál épületen belül végezhető, és 66,10\%-ánál nem érhető el.

A négyér-angiográfia a válaszadók $45 \%$-ánál hozzáférhető, 18,64\%-ánál 0-24 órában, 13,56\%-ánál készenléti ügyeletben, 11,86\%-ánál kizárólag munkaidőben van lehetőség a kivitelezésre, míg a válaszadók 55,93\%-ánál nem érhető el a vizsgálat. Ez a vizsgálat 35,59\%-ban az épületen belül, illetve 8,47\%-ban másik épületben végezhető el.

A perfúziós szcintigráfia elérhetősége nagyon korlátozott, a kórházak 86,44\%-ában nem érhető el, és mindösszesen 13,56\%-nál van lehetőség kivitelezni, kizárólag munkaidőben. A vizsgálat 8,47\%-nál az épületen belül és 5,08\%-nál másik épületben kivitelezhető (6. táblázat).

\section{Szövettani vizsgálat}

Kérdőívünkben kitértünk a szövettani vizsgálat elérhetőségének elemzésére, hiszen előfordul olyan eset, hogy a szervkivétel alatt talál a szervkivevő sebész malignitásra utaló elváltozást, és szövettan elvégzése indokolt, valamint a szervkivétel kezdetének időzítését is befolyásolhatja egy korábbi gyanú vagy igazolt anamnesztikus adat. A válaszadó kórházak $(\mathrm{n}=56$ ) 78,57\%-ánál kizárólag munkaidőben, 7,14\%-nál munkaidőn túl készenléti ügyeleti rendben, 12,50\%-nál egyáltalán nem, és csupán 1,79\%-nál érhető el a vizsgálat nonstop (7. táblázat). 
6. táblázat

A kiváltó vizsgálatok elérhetősége magyarországi intenzív osztályokon

\begin{tabular}{|c|c|c|c|}
\hline \multicolumn{4}{|l|}{ Kiváltó vizsgálatok } \\
\hline & $\begin{array}{l}\text { Transcranialis } \\
\text { Doppler }\end{array}$ & $\begin{array}{l}\text { Négyér- } \\
\text { angiográfia }\end{array}$ & $\begin{array}{l}\text { Perfúziós } \\
\text { szcintigráfia } \\
\text { Tc99m } \\
\text { HMPAO }\end{array}$ \\
\hline Elemszám & 59 & 59 & 59 \\
\hline Igen, 0-24 órában & $3(5,08 \%)$ & $11(18,64 \%)$ & $0(0 \%)$ \\
\hline $\begin{array}{l}\text { Készenléti ügyelet } \\
\text { (Telefonos behívás) }\end{array}$ & $5(8,47 \%)$ & $8(13,56 \%)$ & $0(0 \%)$ \\
\hline $\begin{array}{l}\text { Kizárólag munkaidő- } \\
\text { ben (08:00-16:00) }\end{array}$ & $10(16,95 \%)$ & $7(11,86 \%)$ & $8(13,56 \%)$ \\
\hline Nem elérhető & $41(69,49 \%)$ & $33(55,93 \%)$ & $51(86,44 \%)$ \\
\hline \multicolumn{4}{|l|}{ Vizsgálat helye } \\
\hline & $\begin{array}{l}\text { Transcranialis } \\
\text { Doppler }\end{array}$ & $\begin{array}{l}\text { Négyér- } \\
\text { angiográfia }\end{array}$ & $\begin{array}{l}\text { Perfúziós } \\
\text { szcintigráfia } \\
\text { Tc99m } \\
\text { HMPAO }\end{array}$ \\
\hline Ágy mellett & $18(30,51 \%)$ & $0(0 \%)$ & $0(0 \%)$ \\
\hline Épületen belül & $2(3,39 \%)$ & $21(35,59 \%)$ & $5(8,47 \%)$ \\
\hline Másik épületben & $0(0 \%)$ & $5(8,47 \%)$ & $3(5,08 \%)$ \\
\hline Nem kivitelezhetó & $39(66,10 \%)$ & $33(55,93 \%)$ & $51(86,44 \%)$ \\
\hline
\end{tabular}

A 2016-ban megvalósult szervkivételek $(\mathrm{n}=182)$ 35,16\%-a esett munkaidőre (7-15 óra közé), 64,84\%ban történt a szervkivétel ügyeleti időben, ebben az esetben 8,93\%-ban biztosítható szövettani háttér, melynek elérhetősége nagyban befolyásolja a szervkivétel kezdési időpontját, amennyiben az elkészült képalkotó vizsgálatokon eltérés látható. Ilyen esetekben a centrumba viszszaérkezés időpontját célszerü akkorra időzíteni, amikor már megoldott a szövettan elvégzése, amely a végleges keresztpróba-vizsgálattal párhuzamosan és további időveszteség nélkül készülhet el (7. táblázat).

\section{Laboratóriumi eredmények}

Központi laboratórium minden kórházban elérhető. Mikrobiológiai laboratóriumi vizsgálat 23,73\%-ban érhető el 0-24 órában, 33,90\%-ban kizárólag munkaidőben; 15,25\%-ban munkaidőn kívül elérhető készenléti ügyelet, illetve 27,12\%-ban egyáltalán nem érhető el a vizsgálat.

A válaszadó kórházak mindegyikében elérhetők a nap 24 órájában a donorértékeléshez kötelezően elvégzendő laboratóriumi vizsgálatok, mint például általános kémia, teljes vérkép, haemostasis.

A teljes vizelet- és üledékvizsgálat 59 válaszadó kórház mindegyikében elérhető legalább munkaidőben. A marginális donorszervek értékelésekor ritkán igényelt vizsgálatok (mint totál protein/kreatinin hányados, vizeletkreatinin, MALU/kreatinin hányados) elérhetőségére is rákérdeztünk.
7. táblázat | Szövettani vizsgálat elérhetősége magyarországi intenzív osztályokon

\begin{tabular}{lc}
\hline Szövettani vizsgálat elérhetőség $(\mathrm{n}=56)$ & $1(1,79 \%)$ \\
\hline Igen, 0-24 órában & $4(7,14 \%)$ \\
\hline Készenléti ügyelet (Telefonos behívás) & $44(78,57 \%)$ \\
\hline Kizárólag munkaidőben $(08: 00-16: 00)$ & $7(12,50 \%)$ \\
\hline Nem elérhető & \\
\hline Szervkivétel időpontja $(\mathrm{n}=182)$ & $64(35,16 \%)$ \\
\hline Munkaidőben $(7-15 \mathrm{~h})$ & $118(64,84 \%)$ \\
\hline Ügyeleti időben
\end{tabular}

A leletek továbbküldési lehetősége megoldott az esetek 93,10\%-ában. Vérgázgép 94,92\%-ban az osztályon, 5,08\%-ban az épületen belül áll rendelkezésre.

\section{Következtetések}

Az OTNY-lekérdezési jogosultság szempontjából meglepő, hogy három, korábban donort jelentő kórháznál (a legutóbbi donorjelentésük a 2016-os évben volt) nincs erre kijelölt egészségügyi dolgozó. Kérdés, hogy egy osztályon kezelt súlyos agykárosodott beteg agyhalála esetén ki és hogyan ellenőrizné a tiltakozás hiányát, ami a szervdonáció kötelező előfeltétele.

A minőségi ellátást biztosító személyi feltételek teljesülése nélkülözhetetlen a kritikus állapotú betegek ellátásában. Az egy betegágyra jutó orvosok száma csökkent, míg az ápolók száma kisebb mértékben javult, azonban 2002-ben, 2008-ban és 2017-ben sem éri el a jogszabályban meghatározott minimumot.

Az OEP részéról $d r$. Gresz Miklós elemezte 2011. évi cikkében az intenzív osztályok kihasználtságát [5-7]. A szerző az intenzív osztályok egészségbiztosítónak jelentett forgalmi adatai alapján bemutatta, hogy az ágyak egyetlen naptári napon sem érték el a 75\%-os telítettséget. Ez a tény a donációs szándékkal átadni szándékozott betegek szempontjából is fontos információ. Feltételezi ugyanakkor, hogy az intenzív osztályos kapacitásnak vélhetően elsősorban inkább létszámbeli, mint infrastrukturális akadálya van. Meg kell jegyezni, hogy az OEP felé jelentett intenzív osztályos teljesítményadatok, valamint ágykihasználási adatok csak korlátozottan értékelhetők, és számos tényező torzítja őket [8].

Kohn 2011-ben az Egyesült Államokban azt vizsgálta, hogy ha a sürgősségi ellátásban dolgozó (684 orvos és 438 ápoló) személyzetnek az utolsó szabad helyre egy általa azonosítható, súlyos beteget vagy egy potenciális donort kellene felvennie, milyen motivációk szerint hozzák meg a döntést [9]. A publikált eredmények szerint a döntést mindkét csoportban jobban befolyásolta az azonosítható beteg irányában érzett elköteleződés, mint az általuk nem ismert betegek érdeke és a döntés életévekben mérhető társadalmi hasznossága. Egy kapacitása ha- 
tárait feszegető osztály irányításáért felelős orvos döntését befolyásolhatja ez a tényező olyan formában is, hogy tudja-e vállalni a már meglévő betegek ellátása mellett azt a többletfeladatot, amely közvetett értelemben vezet betegek gyógyulásához, megmentéséhez.

A potenciális donor gondozása jelentős többletfeladatot ró a kórházra mind az ellátás, mind a számos szervezési feladat terén, amelyre erőforrást allokálni kihívást jelent még a jobb feltételekkel rendelkező intézményeknek is. A késői donorfelismerés vezethet beékelődés körüli keringés-összeomláshoz, vagy a fiziológiai változások olyan visszafordíthatatlan károsodást okozhatnak, hogy a potenciális donor szervei alkalmatlanná válnak az átültetésre. Összességében a személyi tényezők oldaláról a szerzők a maguk részéról a legfontosabbnak egy-egy adott intenzív osztályos team, illetve vezetője szakmai elkötelezettségét és az ennek megfelelően kialakított szakmai környezetet tartják, mert a szervdonációk számát az intenzív osztályokon dolgozók donációhoz kapcsolódó attitûdje, szakképzettsége, az agyhalál-koncepció elfogadása befolyásolja [10].

A folyamatosan növekvő várólisták és a transzplantálható szervek számának növelése iránti igény vezetett a donorkritériumok kiterjesztéséhez. Az egyre nagyobb esetszámmal nyert tapasztalatoknak köszönhetően a marginális donorszervek transzplantációs célú felhasználása - megfelelő értékelés és betegkiválasztás mellett eredményessé vált. A marginális donorok kivizsgálása pedig többletterhet ró a kórházakra költségek és erőforrás tekintetében is. A donorértékelés több, akár speciális, költséges vizsgálatot igényel, melyek más esetekben fel sem merülnek. Kisebb betegforgalmú, alacsony progresszivitási szintű intézményekben ezek a feltételek kevésbé adottak. Ugyanezekből a kórházakból épp a méretük és jellegük miatt jellemzően kevesebb donorjelentés érkezik, és nagyobb eséllyel marginális donorokról. Magunk úgy véljük, hogy a potenciális donorok felismerésére és gondozására valamennyi, az intenzív betegellátásra akkreditált intenzív osztálynak alkalmasnak kell lennie. Adataink is mutatják, hogy az agyhalál-diagnosztika és a potenciális donorok vizsgálatához szükséges múszeres háttér a kisebb ellátóhelyek vonatkozásában nem áll maradéktalanul rendelkezésre. Ugyanakkor az is tény, hogy az egészségügyi szerkezetátalakítás 2010 óta zajló folyamatában a funkcionális kórházi integráció lehetőséget nyújt a potenciális agyhalottaknak/donoroknak az agyhalál-diagnosztika és a donorgondozás nagyobb múszeres felkészültséget igénylő lehetőségeivel rendelkező kórházakba való továbbítására. Ez a gyakorlat néhány régióban részben már múködik is. Véleményünk szerint finanszírozási és szakmai ösztönzőkkel erôsíteni és szélesíteni kell ezt a gyakorlatot. A szükséges vizsgálatok lehetőségének hiánya miatt kevesebb szervet tarthatnak alkalmasnak a transzplantációs centrumok, vagy maga a donáció is meghiúsulhat. A meghiúsult donorjelentések a sikerélmény elmaradását jelentik, így csökkentik a mo- tivációt. Összefoglalva, a tárgyi feltételek hiánya közvetve csökkenti a donációs aktivitást.

Az intenzív osztályok személyi és tárgyi feltételeinek biztosítása messze túlmutat a szervdonációs szükségleteken, azonban azt is befolyásoló, jelentős előfeltétel. Az eredmények alapján fejlesztési javaslatokat fogalmazunk meg az erőforrás-felhasználás optimalizálásának, valamint a minőség és a biztonság javításának érdekében, ideértve a finanszírozás aktualizálását, a kórházi koordináció kiterjesztését az intézményi szintű donációs potenciál és gyakorlat vizsgálata céljából.

Anyagi támogatás: A közleménye megírása és a kapcsolódó kutatómunka anyagi támogatásban nem részesült.

Szerzői munkamegosztás: M. S.: A vizsgálat céljának, tárgyának és módszerének kidolgozása, a kérdőív szerkesztése, adatgyüjtés, az eredmények rögzítése, értékelése, statisztikai elemzés, a publikáció szövegezése. E.-V. A.: Adatgyüjtés, az eredmények rögzítése, értékelése. H. E., M. A.: Az eredmények értékelése. K. K.: Adatgyüjtés, a kérdőív szerkesztése. E. E., Sz. B.: A kérdőív elkészítése, az eredmények értékelése. S. A.: Statisztikai elemzés, az eredmények értékelése. N. J.: Az eredmények értékelése, az angol absztrakt elkészítése. A cikk végleges változatát valamennyi szerző elolvasta és jóváhagyta.

Érdekeltségek: A szerzőknek nincsenek érdekeltségeik.

\section{Köszönetnyilvánítás}

A szerzők ezúton fejezik ki köszönetüket a kérdőív kitöltésében részt vevő 59 intenzív osztály dolgozóinak.

\section{Irodalom}

[1] Directive 2010/53/EU of the European Parliament and of the Council of 7 July 2010 on standards of quality and safety of organs intended for transplantation. Official Journal of the European Union, L207, 6.8.2010, pp. 14-29. [accessed: July 27, 2017]. [Az Európai Parlament és a Tanács 2010/53/EU irányelve (2010. július 7.) az átültetésre szánt emberi szervekre vonatkozó minőségi és biztonsági előírásokról.] Az Európai Unió Hivatalos Lapja, L207, 201.8.6., 14-29. o. [Hungarian]

[2] Global observatory on donation and transplantation data. Available from: http://www.transplant-observatory.org [accessed: July 27, 2017].

[3] Transplantation background \& mission. Available from: https:// www.edqm.eu/en/background-mission [accessed: July 30, 2017].

[4] Hungarian National Blood Transfusion Service, Organ Coordination Office. Annual Report 2016. [Szakmai beszámoló 2016, Országos Vérellátó Szolgálat, Szervkoordinációs Iroda.] Available from: http://www.ovsz.hu/sites/ovsz.hu/files/szervadomanyozas_dokumentum/szakmaibeszamolo2016-20170707_ z5.pdf [accessed: July 26, 2017].

[5] Gresz M. Impact of reorganization of the Hungarian system of intensive care units in 2012. [Az intenzív osztályok 2012. évi átalakításának hatása Magyarországon.] Orv Hetil. 2016; 157: 1757-1761. [Hungarian] 
[6] Gresz M. Parameters of bed occupancy of intensive care units in Hungary. [A magyarországi intenzív osztályok kihasználtságának néhány paramétere.] Orv Hetil. 2011; 152: 946-950. [Hungarian]

[7] Gresz M. Some more parameters of utilization of intensive care units in Hungary. [Az intenzív osztályok kihasználtságának néhány újabb paramétere.] Orv Hetil. 2011; 152: 1813-1817. [Hungarian]

[8] Gál J, Fülesdi B. The national Intensive care unit system needs conceptional transformation. [Koncepcionális átalakulásra szorul a hazai intenzív ellátás.] Orv Hetil. 2011; 152: 945. [Hungarian]
[9] Kohn R, Rubenfeld GD, Levy MM, et al. Rule of rescue or the good of the many? An analysis of physicians' and nurses' preferences for allocating ICU beds. Intensive Care Med. 2011; 37: 1210-1217.

[10] Roels L, Spaight C, Smits J, et al. Critical care staffs' attitudes, confidence levels and educational needs correlate with countries' donation rates: data from the Donor Action database. Transplant Int. 2010; 23: 842-850.

(Mihály Sándor dr., Budapest, Karolina út 19-21., 1113 e-mail: mihaly.sandor@ovsz.hu)

\section{NOTA}

Új fejlesztés az egészségügyben dolgozók, tanulók részére!

\section{A magyar nyelvứ szakirodalmi keresőszolgáltatás}

\section{Mi a NOTA?}

Napivizit Orvosi Tudástár Alkalmazás

Mit tud a NOTA portál?

Megkönnyíti a magyar nyelvú szakirodalmi források keresését.

Eszköztől függetlenül, akár okostelefonról, a betegágy mellett állva is használható.

\section{Miben kereshet a NOTA-val?}

Az Akadémiai Kiadó folyóirataiban: Orvosi Hetilap, Magyar Sebészet, Mentálhigiéné és Pszichoszomatika.

Más kiadók magyar nyelvú szakfolyóirataiban: pl. Lege Artis Medicinae, Hypertonia és Nephrologia, Ideggyógyászati Szemle.

A hatályos szakmai irányelvekben.

Magyar nyelvü kérdésekre adott angol nyelvű találatokban, a PubMeden.

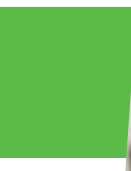

\section{nota.hu}

Amennyiben további információra lenne szüksége,

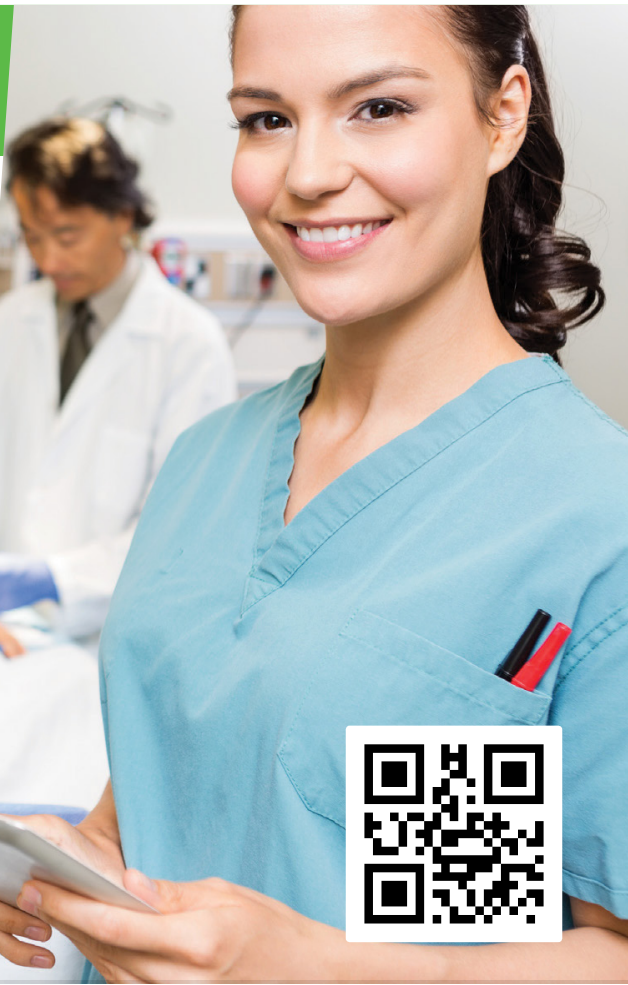

\section{Akadémiai Kiadó}

A Wolters Kluwer Csoport tagja

1117 Budapest, Prielle Kornélia u. 21-35. / Telefon: (1) 464-8246

www.akademiai.hu / www.akademiai.com

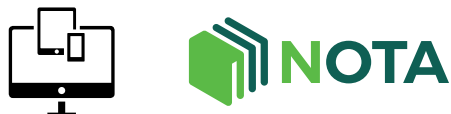

A cikk a Creative Commons Attribution-NonCommercial 4.0 International License (https://creativecommons.org/licenses/by-nc/4.0) feltételei szerint publikált Open Access közlemény, melynek szellemében a cikk nem kereskedelmi célból bármilyen médiumban szabadon felhasználható, megosztható és újraközölhető, feltéve, hogy az eredeti szerzỏ és a közlés helye, illetve a CC License linkje és az esetlegesen végrehajtott módositások feltüntetésre kerülnek. 